\title{
STUDI KOMPARATIF VOLUME PENJUALAN MOBIL BARU SEBELUM DAN SESUDAH DITERAPKAN PAJAK PROGRESIF KENDARAAN BERMOTOR RODA EMPAT DI KABUPATEN BULELENG PADA DEALER MOBIL DI KECAMATAN BULELENG PERIODE 2011-2017
}

\author{
Wayan Suyestini1, Kadek Rai Suwena1, Nyoman Sujana1 \\ Jurusan Pendidikan Ekonomi \\ Universitas Pendidikan Ganesha \\ Singaraja, Indonesia
}

Email: \{suyestini5640@gmail.com1,kadek.suwena@undiksha.co.id1\}

\begin{abstract}
Abstrak
Peneltian ini bertujuan untuk membandingkan volume penjualan mobil sebelum dan sesudah diterapkan pajak progresif kendaraan bermotor roda empat di Kabupaten Buleleng pada dealer mobil di Kecamatan Buleleng. Penelitian ini merupakan jenis peneltian komparatif dengan menggunakan data sekunder yang didapat dari lembaga pengumpul data. Pengumpulan data yang digunakan adalah dokumentasi. Metode analisis data menggunakan uji paired sample T-Test dengan menggunakan program pengolahan data SPSS 16.0 for windows. Hasil dari penelitian ini bahwa untuk mobil merk Toyota tidak terdapat perbedaan volume penjualan, sedang kan mobil merk Daihatsu, merk Mitsubishi, dan merk Suzuki terdapat perbedaan volume penjualan sebelum dan sesudah penerapan pajak progresif.
\end{abstract}

Kata Kunci: Pajak Progersif, Volume Penjualan Mobil

Abstract

This study aimed at comparing the sales volume of cars before and after the implementation of progressive tax of four-wheel vehicles in Buleleng Regency at car dealers in Buleleng District. This study is comparative study which used secondary data obtained from data collector institutions.. Data was collected by means of documentation. The data analysis method was T-test paired sample test assisted by data analysis program SPSS 16.0 for windows. The results of the analysis, it could be concluded that there was no difference in the sales volume of Toyota new cars, while there were differences in the sales volume of Daihatsu, Mitsubishi and Suzuki before and after the implementation of progressive tax

Key words: Progressive Tax, Car Sales Volume

\section{PENDAHULUAN}

Menurut UU No.28 Tahun 2007

Pasal 1 Tentang Ketentuan Umum dan Perpajakan, Pajak merupakan suatu konstribusi wajib kepada negara yang terhutang oleh setiap orang maupun badan yang sifatnya memaksa namun tetap berdasarkan pada Undang-Undang, dan tidak mendapat imbalan secara langsung serta digunakan untuk kebutuhan negara juga kemakmuran rakyatnya Rosdiana \& Edi , 2014).
Menurut Mardiasmo (2011) pajak mempunyai dua fungsi, yaitu: fungsi budgetair, pajak sebagai sumber dana bagi pemerintah untuk membiayai pengeluaranpengeluarannya dan fungsi regulator, pajak sebagai alat untuk mengatur atau melaksanakan kebijaksanaan pemerintah dalam bidang sosial dan ekonomi

Menurut golongannya terdapat dua jenis pajak yang diklasifikasikan, yaitu pajak langsung dimana pajak yang harus dipikul sendiri oleh wajib pajak dan tidak dapat 
dibebankan atau dilimpahkan kepada orang lain, contohnya pajak penghasilan, dan pajak tidak langsung, dimana pajak yang pada akhirnya dapat dibebankan atau dilimpahkan kepada orang lain. Contohnya pajak pertambahan nilai (Mardiasmo, 2011).

Menurut sifatnya pajak dapat dibedakan menjadi dua jenis yaitu pajak subjektif yang berdasarkan pada subjeknya, dalam artian memperhatikan keadaan diri wajib pajak, seperti pajak penghasilan dan pajak objektif yang berpangkal pada objeknya tanpa memperhatikan keadaan diri wajib pajak, seperti pajak pertambahan nilai dan pajak penjualan atas barang mewah(Mardiasmo, 2011).

Dilihat dari lembaga pemungutnya, pajak dibedakan menjadi pajak pusat dan pajak daerah, dimana pajak pusat merupakan pajak yang dipungut pemerintah pusat dan digunakan untuk membiayai rumah tangga Negara, seperti pajak penghasilan, pajak pertambahan nilai, pajak penjualan atas barang mewah dan bea materai. Pajak daerah merupakan pajak yang dipungut oleh pemerintah daerah dan digunakan untuk membiayai rumah tangga daerah, terdiri atas pajak provinsi: pajak kendaraan bermotor dan pajak bahan bakar kendaraan bermotor, dan pajak kabupaten atau kota : pajak hotel, pajak restoran dan pajak hiburan (Mardiasmo, 2011).

Salah satu jenis pajak yang ada di Indonesia yaitu pajak daerah. Menurut Undang-undang No.28 Tahun 2009 pajak daerah adalah konstribusi wajib kepada daerah yang terutang oleh orang pribadi atau badan yang bersifat memaksa berdasarkan Undang-Undang, dengan tidak mendapatkan imbalan secara langsung dan digunakan untuk keperluan daerah bagi sebesar-besarnya kemakmuran rakyat (Soebechi, 2011). Menurut Mardiasmo (2011) pajak daerah adalah iuran wajib yang dilakukan oleh daerah kepada orang pribadi atau badan tanpa imbalan langsung yang seimbang, yang dapat dipaksakan berdasarkan Peraturan PerundangUndangan yang berlaku, yang digunakan untuk membiayai penyelenggaraan pemerintah daerahdan pembangunan daerah.
Dengan demikian, pajak daerah merupakan pajak yang ditetapkan oleh pemerintah daerah dengan Peraturan Daerah (Perda), yang wewenang pemungutannya dilaksanakan oleh pemerintah daerah dan hasilnya digunakan untuk membiayai pengeluaran pemerintah daerah dalam melaksanakan penyelenggaraan pemerintahan dan pembangunan didaerah. Pengenaan tarif pajak daerah salah satunya adalah pengenaan tarif pajak progresif.

Salah satu pajak provinsi yang merupakan bagian dari pajak daerah adalah pajak kendaraan bermotor. Pajak kendaraan bermotor menurut Undangundang No. 28 tahun 2009 tentang pajak daerah dan retribusi daerah adalah pajak atas kepemilikan dan/atau penguasaan kendaraan bermotor. Dasar pengenaan kendaraan bermotor adalah nilai jual kendaraan bermotor dan bobot yang mencerminkan kadar kerusakan jalan dan pencemaran lingkungan akibat penggunaan kendaraan bermotor tersebut. Nilai jual kendaraan bermotor sesuai dengan harga pasar kendaraan bermotor, berat total kendaraan bermotor serta dokumen impor jenis kendaraan tertentu. Masa pajak kendaraan bermotor adalah 12 (dua belas) bulan berturut-turut yang merupakan tahun pajak terhitung sejak tanggal pendaftaran.

Objek pajak kendaraan bermotor adalah kepemilikan dan/atau penguasaan kendaraan bermotor. Kendaraan bermotor adalah semua kendaraan beroda beserta gandengannya yang digunakan di semua jenis jalan darat dan digerakkan oleh peralatan teknik berupa motor atau peralatan lainnya yang berfungsi untuk mengubah suatu sumber daya energi tertentu menjadi tenaga gerak kendaraan bermotor yang bersangkutan, termasuk alat-alat berat dan alat-alat besar yang dalam operasinya menggunakan roda dan motor dan tidak melekat secara permanen.

Subjek pajak kendaraan bermotor adalah orang pribadi, badan, pemerintah, pemerintah daerah, TNI dan Polri yang memiliki dan/atau menguasai kendaraan bermotor. Wajib pajak kendaraan bermotor adalah orang pribadi, badan, pemerintah, pemerintah daerah, TNI dan Polri yang memiliki dan/atau menguasai kendaraan 
bermotor dan/atau kendaraan khusus atau alat-alat berat dan besar.

Dalam sistem perpajakan di Indonesia, terdapat dua jenis pajak yang menerapkan sistem pajak progresif, yaitu Pajak Penghasilan yang merupakan pajak Negara, dan Pajak Kendaraan Bermotor yang merupakan Pajak Provinsi (Mardiasmo, 2011). Pajak Progesif merupakan presentase tarif yang digunakan semakin besar bila jumlah yang dikenai pajak semakin besar (Mardiasmo, 2011). Pajak Progresif dikenal di Indonesia untuk mengatasi kesenjangan antara masyarakat yang berpenghasilan tinggi dengan masyarakat yang berpenghasilan rendah. Hal tersebut menyebabkan tarif pemungutan pajak akan semakin meningkat apabila jumlah atau kuantitas objek pajak semakin banyak dan jika nilai objek pajak mengalami kenaikan.

Pajak progresif diterapkan bagi kendaraan pribadi baik roda dua dan roda empat dengan nama pemilik dan alamat tempat tinggal yang sama. Jika nama pemilik dan alamatnya berbeda, maka tidak dikenakan pajak progresif. Pajak progresif ini tidak berlaku untuk kendaraan dinas pemerintahan dan kendaraan angkutan umum. Kebijakan tarif Pajak Kendaraan Bermotor juga diarahkan untuk mengurangi tingkat kemacetan di daerah perkotaan dengan memberikan kewenangan daerah untuk menerapkan tarif pajak progresif untuk kepemilikan kendaraan kedua dan seterusnya.

Pajak merupakan salah satu faktor yang mempengaruhi volume penjualan. Menurut Alma, (2007) salah satu faktornya adalah pemerintah, dalam kondisi tertentu peran pemerintah sangat menunjang kenaikan penghasilan produsen, dengan kebijakan-kebijakan pemerintah produsen bisa menaikkan atau menurunkan pendapatan. Contohnya dengan kebijakan pemerintah menerapkan pajak progresif pada kendaraan roda empat di seluruh wilayah Indonesia, sehingga diduga dapat menurunkan tingkat penjualan mobil di dealer mobil baru di kecamatan Buleleng.

$$
\text { Menurur Taylor (2005: 84) }
$$

penjualan dipengaruhi oleh 2 faktor lingkungan yaitu: Faktor lingkungan tak terkendali dan faktor lingkungan terkendali. \begin{tabular}{lrr}
\multicolumn{2}{c}{ Faktor lingkungan tak terkendali } \\
adalah faktor yang mempengaruhi \\
pemasaran termasuk & penjualan \\
perusahaan yang berbeda di luar
\end{tabular} perusahaan, faktor-faktor lingkungan tak terkendali antara lain: sumber daya dan tujuan perusahaan, lingkungan persaingan, lingkungan ekonomi dan teknologi, lingkungan politik dan hukum, lingkungan sosial dan budaya. Dimana hukum merupakan peraturan yang ditetapkan oleh pemerintah yang menyangkut perdagangan, perpajakan, kebijakan moneter dan sebagainya.

Faktor lingkungan terkendali adalah faktor lingkungan yang mempengaruhi pemasaran termasuk penjualan yang berada di dalam perusahaan. Faktor-faktor tersebut adalah Marketing Mix terdiri dari:Produk, Harga Jual, Distribusi, Biaya Promosi

Menurut Gubenur Bali pada tanggal 28 April 2014 di hadapan para undangan yang dihadiri ketua-ketua komisi di DPRD Prov. Bali, Kapolda Bali, Majelis Ulama Desa, Sekretaris Daerah Prov. Bali Cokorda Ngurah Pemayun yang diwakili Asisten III (Bidang Administrasi Umum) I Made Santha yang dilansir melalui berita harian Dispenda yang diakses pada tanggal 30 April 2014 dalam sambutannya menyatakan

"Pajak progresif yang akan kita laksanakan adalah sebuah amanat UU. No. 28 Tahun 2009 tentang Pajak Daerah dan Restribusi Daerah yang dituangkan pelaksanaannya dalam perda Prov. Bali No.1 Tahun 2011 tentang Pajak Daerah yang seyogyanya telah kita laksanakan tahun 2011. Maka dari itu pelaksanaan Pajak Profresif bagi kendaraan roda empat fungsi pribadi dan akan kita launching penerapannya pada Juni 2014 di seluruh UPT. Samsat se-Bali"

Menurut Sekretaris Komisi II DPRD Bali Gede Kesuma Putra yang dilansir melalui berita harian Antara Bali yang diakses pada tanggal 2 September 2016 menyatakan bahwa :

"Lalu lintas di berbagai jalan di wilayah kita semakin macet oleh peningkatan jumlah kendaraan. Karena itu perlu diterapkan pajak progresif, yakni untuk kepemilikan kendaraan kedua dan seterusnya lebih tinggi dibandingkan kendaraan pertama, dasar hukum penerapan pajak tersebut 
juga sudah jelas, yakni Undang Undang Nomor 28 Tahun 2009 tentang Pajak Daerah dan Retribusi Daerah (PDRD)".

Fenomena penetapan pajak progresif ini tentunya mendapat berbagai macam respon oleh masyarakat. Salah satu respon yang dapat dilihat dari masyarakat terhadap penerapan pajak progresif ini adalah pada minat masyarakat untuk membeli mobil baru. Hal itu dikarenakan pajak progresif ini akan dikenakan untuk kendaraan bermotor roda empat atau mobil. Data jumlah penjualan mobi lbaru di Kecamatan Buleleng dari tahun 2013 sampai dengan 2016 nampak pada Tabel 1.

Tabel 1. Jumlah Penjualan Mobil Baru Tahun 2013-2016

\begin{tabular}{|c|c|c|c|}
\hline \multirow[t]{2}{*}{ Tahun } & \multicolumn{3}{|c|}{ Dealer Mobil } \\
\hline & $\begin{array}{c}\text { Sun Star } \\
\text { Motor }\end{array}$ & Suzuki & $\begin{array}{l}\text { Agung } \\
\text { Toyota }\end{array}$ \\
\hline 2013 & 448 unit & 534 unit & 822 unit \\
\hline 2014 & 460 unit & 492 unit & 677 unit \\
\hline 2015 & 308 unit & 424 unit & 445 unit \\
\hline 2016 & 188 unit & 411 unit & 473 unit \\
\hline $\begin{array}{l}\text { Sumber } \\
2016\end{array}$ & jiakses 0 & berbag & sumber, \\
\hline
\end{tabular}

Dari data yang telah disajikan, dapat dilihat bahwa terjadi fluktuasi tingkat penjualan pada dealer-dealer tersebut. Seperti pada dealer Sun Star Motor terjadi peningkatan penjualan dar itahun 2013 denganangka 448 unit mobil ketahun 2014 dengan angka 460 unit mobil, akan tetap iterjad ipenurunan secara beruntun dari 460 unit mobil menjadi308 unit mobil pada tahun 2015 dan188 unit mobil pada tahun 2016. Berbeda halnya dengan dealer Suzuki yang mengalami penurunan penjualan ditahun 2014 dengan angka 492 unit mobil yang kemudian mengalami penurunan pada tahun 2015 dengan angka 424 unit mobil dan tahun 2016 dengan angka 411 unit mobil. Begitu pula dengan Agung Toyota yang mengalami penurunan dari tahun 2014 sampai dengan 2016 dengan tingkat penjualan 822 unit mobil pada tahun 2013, 677 unit mobil pada tahun 2014, 445 unit mobil pada tahun 2015 dan473 unit mobilpadatahun 2016. Berdasarkan data diatas, dapat disimpulkan bahwa rata-rata terjadi penurunan padatingkat penjualan pada tahun 2015 dan 2016. Penurunan tingkat penjualan ini mengidikasikan bahwa adanya pengurangan minat masyarakat terhadap pembelian mobil baru. Dengan kondisi yang demikian, penulis tertarik untuk mengetahui apakah perbedaan penjualan mobil setelah diterapkan pajak progresif. Dari pemaparan di atas, maka penulis tertarik melakukan penelitian ini dengan judul "Studi Komparatif Volume Penjualan Mobil Sebelum dan Sesudah Diterapkan Pajak Progresif Kendaraan Bermotor Roda Empat di Kabupaten Buleleng pada Dealer Mobil di Kecamatan Buleleng Periode 2011-2017".

\section{METODE}

Jenis penelitian dalam penelitian ini menggunakan penelitian komparatif. Menurut Silalahi (2005) penelitian komparatif adalah penelitian yang membandingkan dua gelajala atau lebih. Penelitian komparatif ada dua jenis yaitu komparatif deskritif dan komparatif Korelasional. Menurut Hasan (2002) analisis komparasi atau perbandingan adalah prosedur statistik guna menguji perbedaan diantara dua kelompok data (variabel) atau lebih. Menurut Nazir (2005) penelitian komparatif adalah sejenis penelitian deskriptif yang ingin mencari jawaban mendasar tentang sebab-akibat, dengan menganalisis faktor-faktor penyebab terjadinya ataupun munculnya fenomena tertentu. Penelitian komparatif. Subjek penelitian ini adalah dealer-dealer mobil yang ada di kecamatan Buleleng diataranya yaitu: Agung Toyota Singaraja, Astra Daihatsu Singaraja, PT. Sejahtera Indobali Trada Singaraja, PT. Sun Star Motor Singaraja

Objek penelitian ini adalah penerapan pajak progresif kendaraan bermotor dan tingkat penjualan pada masing-masing dealer tersebut. Sedangkan jenis data yang digunakan dalam penelitian ini adalah data kuantitatif. Data Kuantitatif adalah data yang berbentuk angka (Sugiyono, 2010) seperti data penjualan mobil di setiap dealer mobil yang ada di Kecamatan Buleleng. Untuk sumber data didapat dari data sekunder. Data sekunder merupakan data yang telah dikumpulkan oleh lembaga pengumpul data dan dipublikasikan kepada masyrakat pengguna 
data (Sugiyono 2009) yang dalam hal ini berupa data penjualan mobil pada dealer mobil di Kecamatan Buleleng

Metode pengumpulan data dalam penelitian ini adalah menggunakan data dokumentasi volume penjualan mobil baru yang diambil dari dealer dealer mobil se Kecamatan Buleleng dari tahun 2011-2017

Teknik analisa data yang digunakan dalam penelitian ini adalah menggunakan uji paired t-test apabila data terdistribusi normal dan uji Wilcoxon Signed Rank test apabila data tidak terdistribusi normal. Uji paired t-test adalah uji beda dua sampel berpasangan yaitu memiliki subjek yang sama, namun memiliki perlakuan yang berbeda. Wilcoxon Signed Rank test adalahpengujian hipotesis statistik nonparametrik digunakan ketika membandingkan dua sampel berhubungan, sampel yang sama untuk menilai apakah ada perbedaan pada dua pengukuran pada sampel yang sama (Suryani \& Hendryadi, 2015). Ciri-ciri yang ditemui pada kasus yang berpasangan yaitu satu individu (objek penelitian) dikenai dua perlakuan yang berbeda. Walaupun menggunakan individu yang sama, peneliti tetap memperoleh dua macam data sampel, yaitu data dari perlakuan pertama dan data dari perlakuan kedua. Dengan demikian, suatu pengaruh dapat diketahui dengan cara membandingkan kondisi objek penelitian sebelum dan sesudah perlakuan (Ghozali 2009).

Dalam penelitian ini melakukan Uji normalitas. Uji Normalitas adalah sebuah uji yang dilakukan dengan tujuan untuk menilai sebaran data pada kelompok data atau variabel, apakah data tersebut berdistribusi normal atau tidak berdistribusi normal. Untuk menguji normalitas suatu data dilakukan dengan menggunakan statistik non-parametrik dengan metode satu sampel one-sample Kolmogorof-smirnov (Utama, 2016). Uji ini bertujuan untuk menentukan uji selanjutnya yang harus digunakan terhadap data yang terdistribusi normal dan data yang tidak terdistribusi normal

Dalam penelitian ini Uji Hipotesisyang digunakan untuk mengetahui apakah terdapat perbedaan volume penjualan mobil baru sebelum dan sesudah diterapkan pajak progresif kendaraan bermotor roda empat di seluruh Bali, adalah uji paried sample T-Test dengan menggunakan program SPSS 16.0 for windows, apabila data yang digunakan berdistribusi normal dan apabila data yang digunakan tidak terdistribusi normal maka uji yang digunakan adalah uji Wilcoxon Signed Rank untuk sampel berpasangan. Tingkat signifikan atau nilai alfa $(\alpha)$ yang digunakan adalah 0,05 dan $\mathrm{df}=\mathrm{n}-1$, jika probabilitas lebih kecil dari a 0,05 maka $\mathrm{H}_{1}$ di terima dan jika probabilitas lebih besar dari a 0,05 maka $_{1}$ di tolak.

\section{HASIL DAN PEMBAHASAN Hasil}

Perbedaan Volume Penjualan Mobil merk Toyota di Dealer Agung Toyota Singaraja Sebelum dan Sesudah diterapkan Pajak Progresif Kendaraan Bermotor roda empat di Kabupaten Buleleng. Berdasarkan uji normalitas data volume penjualan mobil merk Toyota di dealer Agung Toyota Singaraja sebelum dan sesudah diterapkan pajak progresif kendaraan bermotor roda empat di Kabupaten Buleleng diperoleh hasil uji normalitas seperti yang tampak pada Tabel 2.

Tabel 2. Hasil Uji Normalitas Volume Penjualan Mobil Baru Merk Toyota

\begin{tabular}{lrr}
\hline & Sebelum & Sesudah \\
\hline Kolmogorov-Smirnov Z & 1.126 & 1.226 \\
Asymp. Sig. (2-tailed) & .159 & .099 \\
a. Test distribution is Normal. & &
\end{tabular}

Sumber: Data Diolah, 2018 
Dari Tabel 2 terlihat bahwa hasil uji normalitasmenunjukan bahwa nilai dari asymp.sig (2-tailed) masing-masing sebelum dan sesudah diterapkan pajak progresif kendaraan bermotor roda empat di Kabupaten Buleleng sebesar 0,159 dan 0,099 . Hal ini menunjukan nilai dari asymp.sig (2-tailed) nilainya lebih besar dari $\alpha=0,05(5 \%)$, sehingga data dapat dikatakan terdistribusi normal.

Berdasarkan hasil pengolahan data volume penjualan mobil baru merk Toyota di dealer Agung Toyota Singaraja sebelum dan sesudah diterapkan pajak progresif kendaraan bermotor roda empat di Kabupaten Buleleng dengan menggunakan uji beda t-test (paried samples test), diperoleh hasil uji beda t-test volume penjualan mobil baru merk Toyota di dealer Agung Toyota Singaraja sebelum dan sesudah diterapkan pajak progresif kendaraan bermotor roda empat di Kabupaten Buleleng nampak pada Tabel 3.

Tabel 3. Hasil Uji Beda t-test Volume Penjualan Mobil Baru Merk Toyota

\begin{tabular}{lccccccc}
\hline & \multicolumn{7}{c}{ Paired Differences } \\
& Mean & $\begin{array}{c}\text { Std. } \\
\text { Deviation }\end{array}$ & $\begin{array}{c}\text { Std. Error } \\
\text { Mean }\end{array}$ & $\begin{array}{c}\text { 95\% Confidence Interval of } \\
\text { the Difference } \\
\text { Lower }\end{array}$ & Upper & Df & $\begin{array}{c}\text { Sig. (2- } \\
\text { tailed) }\end{array}$ \\
\hline $\begin{array}{l}\text { Pair } \\
1\end{array}$ & $\begin{array}{l}\text { Sebelum - } \\
\text { Sesudah }\end{array}$ & 8.237 & 32.560 & 5.282 & -2.466 & 18.9391 .55937 & .127 \\
\hline
\end{tabular}

Sumber: Data Diolah, 2018

Dari hasil uji beda t-test pada Tabel 3 menunjukan bahwa nilai dari asymp.sig (2-tailed) sebesar $0,127>$ dari $\alpha=0,05$ (95\%). Hal ini menunjukan bahwa $\mathrm{H}_{1}$ ditolak. sehingga dapat diketahui bahwa tidak terdapat perbedaan volume penjualan mobil baru merk Toyota di dealer Agung Toyota Singaraja sebelum dan sesudah diterapkan pajak progresif kendaraan bermotor roda empat di Kabupaten Buleleng
Perbedaan Volume Penjualan Mobil Baru merk Daihatsu di Dealer Astra Daihatsu Singaraja Buleleng Sebelum dan Sesudah diterapkan Pajak Progresif Kendaraan Bermotor roda empat di Kabupaten Buleleng. Berdasarkan uji normalitas data volume penjualan mobil baru merk Daihatsu di dealer Astra Daihatsu Singaraja sebelum dan sesudah diterapkan pajak progresif kendaraan bermotor roda empat di Kabupaten Buleleng diperoleh hasil uji normalitas seperti yang tampak pada Tabel 4.

Tabel 4. Hasil Uji Normalitas Volume Penjualan Mobil Baru Merk Daihatsu

\begin{tabular}{lrr}
\hline & Sebelum & Sesudah \\
\hline Kolmogorov-Smirnov Z & .527 & .557 \\
Asymp. Sig. (2-tailed) & .944 & .916
\end{tabular}

a. Test distribution is Normal.

Sumber: Data Diolah, 2018

Dari Tabel 4 terlihat bahwa hasil uji normalitas menunjukan bahwa nilai dari asymp.sig (2-tailed) masing-masing sebelum dan sesudah diterapkan pajak progresif kendaraan bermotor roda empat di Kabupaten Buleleng sebesar 0,944 dan 0,916 . Hal ini menunjukan nilai dari asymp.sig (2-tailed) nilainya lebih besar dari $\alpha=0,05(5 \%)$, sehingga data dapat dikatakan terdistribusi normal.

Berdasarkan hasil pengolahan data volume penjualan mobil baru merk Daihatsu di dealer Astra Daihatsu Singaraja sebelum dan sesudah diterapkan pajak progresif kendaraan bermotor di Kabupaten Buleleng dengan menggunakan uji beda t-test 
(paried samples test), hasil uji beda t-test Volume Penjualan Mobil Baru Merk Daihatsu Di Dealer Astra Daihatsu Singaraja sebelum dan sesudah diterapkan
Pajak Progresif Kendaraan Bermotor roda empat di Kabupaten Buleleng tampak pada Tabel 5.

Tabel 5. Hasil Uji Beda t-test Volume Penjualan Mobil Baru Merk

Paired Differences

\begin{tabular}{|c|c|c|c|c|c|c|c|c|c|}
\hline & & \multirow[b]{2}{*}{ Mean } & \multirow{2}{*}{$\begin{array}{l}\text { Std. } \\
\text { Deviation }\end{array}$} & \multirow{2}{*}{$\begin{array}{l}\text { Std. Error } \\
\text { Mean }\end{array}$} & \multicolumn{2}{|c|}{$\begin{array}{l}\text { 95\% Confidence Interval of the } \\
\text { Difference }\end{array}$} & \multirow[b]{2}{*}{$\mathrm{T}$} & \multirow[b]{2}{*}{ Df } & \multirow{2}{*}{$\begin{array}{l}\text { Sig. }(2- \\
\text { tailed) }\end{array}$} \\
\hline & & & & & Lower & Upper & & & \\
\hline $\begin{array}{l}\text { Pair } \\
1\end{array}$ & $\begin{array}{l}\text { Sebelum - } \\
\text { Sesudah }\end{array}$ & $\begin{array}{r}- \\
7.367\end{array}$ & 10.427 & 1.904 & -11.260 & -3.473 & 3.87 & -29 & .001 \\
\hline
\end{tabular}

Sumber: Data diolah, 2018

Dari hasil uji beda $t$-test pada tabel 5 menunjukan bahwa nilai dari asymp.sig (2tailed) sebesar 0,001 < dari $\alpha=0,05$ (95\%). $\mathrm{Hal}$ ini menunjukan bahwa $\mathrm{H}_{1}$ diterima. sehingga dapat diketahui bahwa terdapat perbedaan volume penjualan mobil baru merk Daihatsu di dealer volume penjualan mobil baru merk Daihatsu di dealer Astra Daihatsu Singaraja sebelum dan sesudah diterapkan pajak progresif kendaraan bermotor roda empat di Kabupaten Buleleng
Perbedaan Volume Penjualan Mobil Baru merk Suzuki di Dealer PT. Indobali Trada Singaraja Sebelum dan Sesudah diterapkan Pajak Progresif Kendaraan Bermotor roda empat di Kabupaten Buleleng. Berdasarkan uji normalitas data volume penjualan mobil baru merk Suzuki di dealer PT. Sejahtera Indobali Trada Singaraja sebelum dan sesudah diterapkan pajak progresif kendaraan bermotor roda empat di Kabupaten Buleleng, diperoleh hasil uji normalitas seperti yang tampak pada Tabel 6.

Tabel 6. Hasil Uji Normalitas Volume Penjualan Mobil Baru Merk Suzuki

\begin{tabular}{lrr}
\hline & Sebelum & Sesudah \\
\hline Kolmogorov-Smirnov Z & .644 & .924 \\
Asymp. Sig. (2-tailed) & .802 & .360 \\
a. Test distribution is Normal. & &
\end{tabular}

\section{Sumber: Data Diolah, 2018}

Dari tabel 6 terlihat bahwa hasil uji normalitas menunjukan bahwa nilai dari asymp.sig (2-tailed) masing-masing sebelum dan sesudah diterapkan pajak progresif kendaraan bermotor roda empat di Kabupaten Buleleng sebesar 0,802 dan 0,360 . Hal ini menunjukan nilai dari asymp.sig (2-tailed) nilainya lebih besar dari $\alpha=0,05(5 \%)$, sehingga data dapat dikatakan terdistribusi normal.

Berdasarkan hasil pengolahan data volume penjualan mobil baru merk Suzuki di dealer PT. Sejahtera Indobali Trada Singaraja sebelum dan sesudah diterapkan pajak progresif kendaraan bermotor roda empat di Kabupaten Buleleng dengan menggunakan uji beda t-test (paried samples test), diperoleh hasil uji beda $t$-test Volume Penjualan Mobil Baru Merk Suzuki di dealer PT. Sejahtera Indobali Trada Singaraja. sebelum dan sesudah diterapkan pajak progresif kendaraan bermotor roda empat tampak pada Tabel 7. 
Tabel 7. Hasil Uji Beda t-test Volume Penjualan Mobil Baru Merk Suzuki

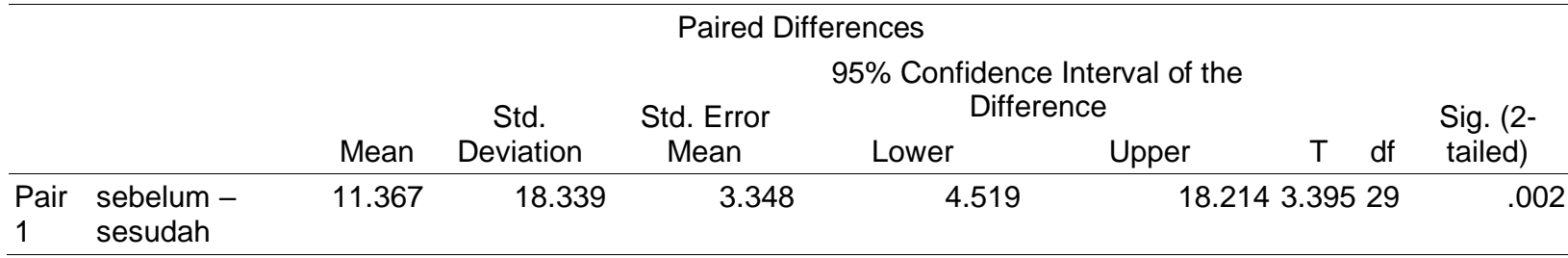

Sumber : Data Diolah, 2018

Dari hasil uji beda $t$-test pada tabel 7 menunjukan bahwa nilai dari asymp.sig (2tailed) sebesar 0,002 < dari $\alpha=0,05(95 \%)$. Hal ini menunjukan bahwa $\mathrm{H}_{1}$ diterima. sehingga dapat diketahui bahwa terdapat perbedaan volume penjualan mobil baru merk Suzuki di dealer PT. Sejahtera Indobali Trada Singaraja sebelum dan sesudah diterapkan pajak progresif kendaraan bermotor roda empat di Kabupaten Buleleng
Perbedaan Volume Penjualan Mobil Baru merk Mitsubishi di Dealer PT. Sun Star Motor Singaraja Singaraja Sebelum dan Sesudah diterapkan Pajak Progresif Kendaraan Bermotor roda empat di Kabupaten Buleleng. Berdasarkan uji normalitas data volume penjualan mobil baru merk Mitsubishi di dealer PT. Sun Star Motor Singaraja sebelum dan sesudah diterapkan pajak progresif kendaraan bermotor roda empat di Kabupaten Buleleng diperoleh hasil uji normalitas seperti yang tampak pada tabel 8 .

Tabel 8. Hasil Uji Normalitas Volume Penjualan Mobil Baru Merk Mitsubishi

\begin{tabular}{lcr}
\hline & Sebelum & Sesudah \\
\hline Kolmogorov-Smirnov Z & .641 & .977 \\
Asymp. Sig. (2-tailed) & .806 & .295
\end{tabular}

a. Test distribution is Normal.

Sumber: Data Diolah 2018

Dari tabel 8 terlihat bahwa hasil uji normalitas menunjukan bahwa nilai dari asymp.sig (2-tailed) masing-masing sebelum dan sesudah diterapkan pajak progresif kendaraan bermotor roda empat di Kabupaten Buleleng sebesar 0,806 dan 0,295 . Hal ini menunjukan nilai dari asymp.sig (2-tailed) nilainya lebih besar dari $\alpha=0,05(5 \%)$, sehingga data dapat dikatakan terdistribusi normal.

Berdasarkan hasil pengolahan data volume penjualan mobil baru merk

Tabel 9. Hasil Uji Beda t-test Volume Penjualan Mobil Baru Merk Mitsubishi

\section{Paired Differences}

\begin{tabular}{cccccccrc} 
& \multicolumn{9}{c}{$95 \%$ Confidence Interval of } \\
& Mean & Std. & \multicolumn{2}{c}{ Std. Error } & \multicolumn{2}{c}{ the Difference } & Sig. (2- \\
& Deviation & Mean & Lower & Upper & T & df & tailed) \\
\hline Pair $1 \begin{array}{l}\text { Sebelum - } \\
\text { Sesudah }\end{array}$ & 10.632 & 17.898 & 2.903 & 4.749 & 16.5153 .66237 & .001 \\
\hline
\end{tabular}

Sumber : Data Diolah, 2018 
Dari hasil uji beda $t$-test pada tabel 9menunjukan bahwa nilai dari asymp.sig (2tailed) sebesar 0,001< dari $\alpha=0,05$ (95\%). Hal ini menunjukan bahwa $\mathrm{H}_{1}$ diterima. sehingga dapat diketahui bahwa terdapat perbedaan volume penjualan mobil baru merk Mitsubishi di dealer PT. Sun Star Motor Singaraja Singaraja sebelum dan sesudah diterapkan pajak progresif kendaraan bermotor roda empat di Kabupaten Buleleng

\section{Pembahasan}

Dari hasil penelitian diketahui bahwa ada dua hasil yang berbeda yaitu pertama, terdapat perbedaan volume penjualan sebelum dan sesudah diterapkan pajak progresif kendaraan bermotor roda empat di Kabupaten Buleleng mobil baru di Dealer Astra Daihatsu Singaraja, Dealer PT. Indobali Trada Singaraja dan Dealer PT Sun Star Motor Singaraja. Kedua tidak terdapat perbedaan volume penjualan sebelum dan sesudah diterapkan pajak progresif kendaraan bermotor roda empat di Kabupaten Buleleng mobil baru di Dealer Agung Toyota Singaraja. Hasil penelitian ini konsisten dengan penelitian yang dilakukan oleh Yunita (2016) dimana hasil penelitiannya menunjukkan penerapan pajak progresif ini memang berdampak pada penjualan mobil baru, namun tidak menjadi faktor yang mendominasi terjadinya penurunan tingkat penjualan mobil, dan penelitian Florians (2014) dimana hasil penelitiannya menunjukkan tidak terdapat pengaruh penerapan pajak progresif terhadap pembelian kendaraan bermotor roda empat pada masyarakat kota Malang

Secara umum penerapan pajak progresif kendaraan bermotor roda empat di Kabupaten Buleleng merupakan kabar buruk (bad news) bagi dunia usaha. Namun ada 1 dealer yang tidak terpengaruh dari penerapan pajak progesif. Sehingga sebagian besar para pengusaha yang yang bergerak dalam bidang industri mobil mengalami penurunan penjualan.

Penelitian ini mendukung teorinya Buchari, Alma (2007) yang menyatakan bahwa faktor-faktor yang mempengaruhi penjualan salah satunya pemerintahan.
Dalam kondisi tertentu peran pemerintah sangat menunjang kenaikan penghasilan produsen, dengan kebijakan-kebijakan pemerintah produsen bisa menaikkan atau menurunkan pendapatan, contohnya dengan peraturan pemerintah menerapkan pajak progresif pada kendaraan roda empat di seluruh wilayah Indonesia, sehingga diduga dapat menurunkan tingkat penjualan mobil. selanjutnya Taylor (2005 : 84) menyatakan bahwa penjualan dipengaruhi oleh 2 faktor lingkungan, salah satunya adalah faktor hukum yang merupakan peraturan yang ditetapkan oleh pemerintah yang menyangkut perdagangan, perpajakan, kebijakan moneter dan sebagainya.

\section{SIMPULAN DAN SARAN Simpulan}

Berdasarkan hasil penelitian dan pembahasan yang telah dilakukan, maka dapat ditarik simpulan pertama, terdapat perbedaan volume penjualan sebelum dan sesudah diterapkan pajak progresif kendaraan bermotor roda empat di Kabupaten Buleleng mobil baru di Dealer Astra Daihatsu Singaraja, Dealer PT. Indobali Trada Singaraja dan Dealer PT Sun Star Motor Singaraja dengan hasil nilai Asymp.Sig. (2 - tailed) masing-masing sebesar 0,001 < a 0,05., 0,002< a 0,05. Dan 0,001 < a 0,05.

Kedua tidakterdapat perbedaan volume penjualan sebelum dan sesudah diterapkan pajak progresif kendaraan bermotor roda empat di Kabupaten Buleleng mobil baru di Dealer Agung Toyota Singaraja dengan hasil nilai Sig. (2tailed) sebesar 0,127 > 0,05.

\section{Saran}

Berdasarkan simpulan di atas, maka saran-saran yang dapat dikemukakan sebagai berikut: Bagi perusaahaan agar mengatur strategi pemasaran yang lebih baik untuk mengatasi penurunan tingkat penjualan mobil agar penjualan mobil bisa optimal sehingga perusahaan nantinya tidak mengalami kebangkrutan dan bagi peneliti selanjutnya yang ingin melakukan 
penelitian di dealer - dealer diharapkan agar memperluas sampel penelitian.

\section{DAFTAR PUSTAKA}

Alma, Butchari. 2007. Manajemen

Pemasaran dan Pemasaran Jasa.

Bandung: Alfabeta

Ghozali, Imam. 2009. Aplikasi Analisis Multivariate dengan program SPSS. Edisi 4. Semarang: Badan Penerbit Universitas Diponegoro.

Hasan, M. lqbal. 2002. Pokok- Pokok Materi Metodologi Penelitian dan Aplikasinya. Bogor: Ghalia Indonesia

Mardiasmo. 2011. Perpajakan Edisi Revisi. Yogyakarta: C.V Andi

Nanang, Martono. 2016. Metode Penelitian Kuantitatif. Jakarta: Fajar Interpratana Mandiri

Rosdiana, H \& Edi. S. 2014. Pengantar IImu Pajak. Jakarta: Fajar Interpratama Offset

Silalahi, Ulber 2005. Metode Peneltian Sosial. Bandung: Unpar Press
Soebechi, Imam. 2013. Judicial Review:Perda Pajak dan Restribusi Daerah. Jakarta: Sinar Grafika

Sugiyono. 2003. Metode peneltian Bisnis. Bandung: Pusat Bahasa Depdiknas
----------. 2009. Metode Penelitian Kuantitatif, Kualitatif dan R\&D. Bandung: Alfabeta
-----------. 2010. Metode Penelitian Kuantitatif, Kualitatif dan R\&D. Bandung: Alfabeta

Suryani dan Hendryadi. 2015. Metode Riset Kuantitatif: Teori Aplikasi pada Penelitian Bidang Manajemen dan Ekonomi Islam. Jakarta: Prenadamedia Group.

Taylor, Fredrick W. 2005. Principles Scientif of Management. Bandung: LPPM

Utama, Made Suyana, 2016. Aplikasi Analisis Kuantitatif: Untuk Ekonomi dan Bisnis. Denpasar: CV Sastra Utama3 
p-ISSN : 2599-1418

e-ISSN : 2599-1426

Jurnal Pendidikan Ekonomi Undiksha

Volume 9 No.2 Tahun: 2017 